\title{
Diffusible Signal Factor-Repressed Extracellular Traits Enable Attachment of Xylella fastidiosa to Insect Vectors and Transmission
}

\author{
Clelia Baccari, Nabil Killiny, Michael Ionescu, Rodrigo P. P. Almeida, and Steven E. Lindow
}

First, third, and fifth authors: Department of Plant and Microbial Biology, and second and fourth authors: Department of Environmental Science, Policy and Management, University of California Berkeley, CA 94720.

Current address of N. Killiny: Citrus Research and Education Center, Department of Entomology and Nematology, University of Florida, IFAS, Lake Alfred, FL.

Accepted for publication 24 July 2013.

\begin{abstract}
Baccari, C., Killiny, N., Ionescu, M., Almeida, R. P. P., and Lindow, S. E. 2014. Diffusible signal factor-repressed extracellular traits enable attachment of Xylella fastidiosa to insect vectors and transmission. Phytopathology 104:27-33.

The hypothesis that a wild-type strain of Xylella fastidiosa would restore the ability of $r p f F$ mutants blocked in diffusible signal factor production to be transmitted to new grape plants by the sharpshooter vector Graphocephala atropunctata was tested. While the $r p f F$ mutant was very poorly transmitted by vectors irrespective of whether they had also fed on plants infected with the wild-type strain, wild-type strains were not

mutant. About 100-fewer cells of a wild-type strain attached to wings of a vector when suspended in xylem sap from plants infected with an $r p f F$ mutant than in sap from uninfected grapes. The frequency of transmission of cells suspended in sap from plants that were infected by the rpfF mutant was also reduced over threefold. Wild-type cells suspended in a culture supernatant of an $r p f F$ mutant also exhibited 10-fold less adherence to wings than when suspended in uninoculated culture media. A factor released into the xylem by $r p f F$ mutants, and to a lesser extent by the wild-type strain, thus inhibits their attachment to, and thus transmission by, sharpshooter vectors and may also enable them to move more readily through host plants.
\end{abstract} efficiently transmitted if vectors had fed on plants infected with the $r p f F$
The xylem-limited bacterium Xylella fastidiosa causes Pierce's disease of grapevine, as well as diseases of other important crop plants and trees $(17,18)$. The bacterium is spread from plant to plant by xylem-sap feeding insect vectors $(14,29,30)$. Any sucking insect specialized to feed primarily on xylem-sap may be a vector (2), although transmission efficiency depends on the vector species and the recipient plant species (22). The foregut is the likely site from which vectors transmit $X$. fastidiosa to plants since there is a loss of transmission ability following molting of infectious vector nymphs $(1,26,28)$ as the cuticle lining of the foregut is shed during molting. In addition, there is no required latent period between vector acquisition of $X$. fastidiosa and its transmission to plants $(26,28)$. X. fastidiosa forms a biofilm on portions of the vector foregut, which is apparently the source of inoculated cells $(2,6,27)$. Studies of the location of $X$. fastidiosa in the foregut of transmitting vectors suggest that the precibarium, a narrow canal leading from the vector's mouthparts to the pump chamber (cibarium) within the foregut, is the most likely site from which $X$. fastidiosa is transmitted by vectors (2).

$X$. fastidiosa exhibits very strong context-dependent behaviors that enable its efficient colonization of both host plants as well as obligatory transmission by insects that is coordinated by cell-cell signaling conferred by the rpf quorum sensing system (7). Diffusible signal factor (DSF), an unsaturated fatty acid, accumulates in populations of $X$. fastidiosa as cell numbers increase. DSF production conferred by the DSF synthase RpfF is perceived by $\mathrm{RpfC}$, initiating a signal transduction cascade leading to altered

Corresponding author: S. E. Lindow; E-mail address: icelab@berkeley.edu

* The $\boldsymbol{e}$-Xtra logo stands for "electronic extra" and indicates that Figure 2 appears in color online.

http://dx.doi.org/10.1094/PHYTO-06-13-0151-R

(c) 2014 The American Phytopathological Society transcription of a variety of genes $(4,7)$. Importantly, a variety of genes encoding fimbrial and afimbrial adhesins are up-regulated by DSF, while genes encoding type IV pili involved in twitching motility as well as those encoding extracellular enzymes such as polygalacturonases and endoglucosidases are repressed in the presence of DSF (7,8,31). While rpfF mutants incapable of DSF production are much more virulent than the wild-type strain in grapevines, cells of this mutant are very poorly transmitted by an efficient vector species (24). The hypervirulence of $r p f F$ mutants of $X$. fastidiosa is associated with their ability to move into a much larger proportion of xylem vessels in inoculated plants, a higher population size in such vessels, as well as a lesser ability to form biofilms in vitro $(8,9)$. Conversely, their poor vector transmission was associated with an apparent inability to colonize sharpshooter vectors, given that few cells were retained in the heads of these vectors when fed on plants infected with the rpfF mutant (24). This pattern of cell density-dependent gene expression has been posited to enable a complex life strategy of $X$. fastidiosa in which it would be free to actively move along and between xylem vessels because of active twitching motility in the absence of adhesiveness (7) since it is not typically found in high numbers in xylem vessels (23) and DSF would thus not have accumulated. In contrast, those cells found in higher numbers in some vessels would have an opposite phenotype and be more readily acquired by vectors.

Given that the absence of DSF in the vicinity of rpfF mutants in plants was apparently responsible for their inability to be acquired by, and thus be transmitted, by sharpshooter vectors, we hypothesized that transmissibility should be restored in vectors in which both the wild-type and $r p f F$ mutant were present since DSF produced by the wild-type strain could enable appropriate gene expression of the mutant. Likewise, it might also be possible for DSF present within $X$. fastidiosa-infected xylem vessels to modulate gene expression of $r p f F$ mutants in vectors that would feed on 
such plants. This study was therefore designed to test this hypothesis of phenotypic complementation of the vector transmissibility of $r p f F$ mutants. Surprisingly, while no evidence for such complementation was obtained, we report evidence that a factor is present in xylem vessels of plants infected by both wild-type $X$. fastidiosa, and particularly rpfF mutants suppress the transmissibility of this pathogen, apparently by blocking its ability to attach to sharpshooter vectors.

\section{MATERIALS AND METHODS}

Bacterial strains and insects. Wild-type $X$. fastidiosa subsp. fastidiosa strains Temecula (23) and STL (15) as well as an rpfF mutant (KLN61) (24) and gfp-marked strain KLN59.3 (23) were used in this study; both mutants were generated in strain Temecula. All wild-type strains were grown on periwinkle gelrite (PWG) media (15) and strains KLN61 and KLN59.3 were grown on PWG containing kanamycin $(100 \mu \mathrm{l} / \mathrm{ml})$. Adults of an efficient vector species, Graphocephala atropunctata (Hemiptera, Cicadellidae), were reared in greenhouse insectaries following standard protocols (11). Adult insects free of $X$. fastidiosa were produced by rearing insects from eggs on sweet basil (Ocimum basilicum) plants; there is no transovarial or trans-stadial transmission of $X$. fastidiosa (13). All insect vectors were prescreened for infectivity with $X$. fastidiosa by caging groups for 4 days on healthy grapevines, which were then held in a greenhouse for 3 months and monitored for Pierce's disease symptoms and the absence of $X$. fastidiosa confirmed by culturing (15); all insect vectors were found to be free of $X$. fastidiosa. Hindwings of another leafhopper vector species (Homalodisca vitripennis) were used to detect attachment of $X$. fastidiosa strains. Wings were washed twice in $80 \%$ ethanol to both remove debris and to surface sterilize the wings, which were dried and stored until use.

Plant inoculations and insect transmission. Source plants of European grapevines, Vitis vinifera ('Cabernet Sauvignon'), were grown in a greenhouse to a height of about $50 \mathrm{~cm}$ and mechanically inoculated with $X$. fastidiosa strains (wild-type Temecula and STL or $r p f F$ mutant) using a droplet puncture method as described before (15). Inoculum consisted of $5 \mu \mathrm{l}$ droplets of a given cell suspension $\left(10^{8}\right.$ cells $\left./ \mathrm{ml}\right)$. Plants were grown in the greenhouse for about 10 weeks after inoculation until initial symptoms of Pierce's disease appeared. The abundance of $X$. fastidiosa was then assessed by dilution plating of petiole macerates on PWG with and without kanamycin as appropriate (15). Only plants that exhibited typical disease symptoms and had high populations of $X$. fastidiosa were used as source plants for subsequent experiments.

Insect transmission studies were conducted similar to that reported previously (24). At least 30 to 40 blue-green sharpshooter (BGSS) were allowed to feed on source plants infected with a given strain of $X$. fastidiosa for 3 days. Insects were then either moved to a healthy plant where they were allowed to feed for 7 days or onto another source plant infected with a different $X$. fastidiosa strain for an additional 3 days before then being caged for a 7-day inoculation access period (IAP) on healthy grapevines. After the end of the IAP, the plants were kept in a greenhouse for 8 weeks, the occurrence of disease symptoms was recorded, and the presence of each strain of $X$. fastidiosa in a given plant was assessed by culturing of petiole macerates on appropriate PWG media as above. After the IAP on healthy plants, the BGSS were removed, surface sterilized (15), and decapitated. Only insects that were alive at the end of the experiment were analyzed. The heads, which contain the foregut, were macerated and $X$. fastidiosa population size was determined by dilution plating of serial dilutions of macerate on either PWG or PWG containing kanamycin as appropriate.

Xylem sap extraction. Mature plants of Thompson seedless grapevine ( $V$. vinifera) showing Pierce's disease symptoms 10 weeks after inoculation with wild-type strain Temecula or an $r p f F$ mutant in the greenhouse were cut into $40 \mathrm{~cm}$ segments consisting of both stem and leaves and placed in a pressure chamber (PMS Instruments Co., Corvallis, OR) with the basal end protruding and subjected to about 20 bar. An average of about $5 \mathrm{ml}$ of xylem sap was expressed from a collection of infected plants while about $10 \mathrm{ml}$ was collected from uninoculated plants. The sap was filtered through a $0.22 \mu \mathrm{m}$ filter and stored at $-80^{\circ} \mathrm{C}$.

Attachment of $\boldsymbol{X}$. fastidiosa to vector hindwings. Cells of the rpfF mutant strain KLN59.3 were suspended to a final concentration of about $10^{8}$ cells $/ \mathrm{ml}\left(\mathrm{OD}_{600}=0.25\right)$ in filtered xylem sap from healthy plants or sap from plants infected with wild-type strain Temecula or KLN61. Cells were also suspended in cell-free supernatant of cultures of wild-type strain Temecula and the rpfF mutant grown in PIM6 medium (5) for 7 days. Cells were removed from culture supernatants by centrifuging twice at $5,000 \times g$ for $10 \mathrm{~min}$. Vector hindwings were submersed in a minimal volume of cell suspension and shaken gently for $2 \mathrm{~h}$ and then rinsed three times in potassium phosphate buffer $(10 \mathrm{mM}, \mathrm{pH} 7.0)$ for $15 \mathrm{~min}$ to remove unbound cells. Wings were then mounted on microscopy slides and covered with a $50 \%$ glycerol solution. Epifluorescence microscopy was performed as described before $(3,20)$ on the same day. The number of cells attached to wings was determined by dilution plating of wing macerates similar to that used to assess colonization of petioles (15).

Artificial diet feeding experiments. $X$. fastidiosa wild-type Temecula strain was grown in $X$. fastidiosa medium (XFM)pectin (19) for 10 days and suspended at a final concentration of $10^{8}$ cells $/ \mathrm{ml}$ in filtered xylem saps as described above. A total of $60 \mathrm{G}$. atropunctata leafhopper adults were allowed to feed individually on cell suspensions in a given xylem sap source through a double layer of parafilm in small cages as previously described for $3 \mathrm{~h}$ (19). After this pathogen acquisition access period (AAP), the number of cells acquired by 10 insects in each treatment was estimated using quantitative polymerase chain reaction (PCR). DNA was extracted from the dissected heads similarly to other studies $(12,20)$. To develop a standard curve, X. fastidiosa DNA was extracted from suspensions of cultured cells while the number of viable cells in these suspensions was determined by plating of serial dilutions on PWG. DNA quantification was performed on a 7500 real-time thermocycler (Applied Biosystems) using primers HL5 and HL6 (8) and using SYBR Green Mix (Applied Biosystems). The acquisition rate was defined as the percentage of insects with any detectable cells of $X$. fastidiosa. The remaining 50 insects for each treatment were caged on healthy grape plants (Cabernet Sauvignon) and 25 insects were collected after a $12 \mathrm{~h}$ IAP while the other 25 insects were collected after $96 \mathrm{~h}$. X. fastidiosa populations in the heads of these insects were estimated using quantitative PCR as above after removal from plants. The plants were kept in a greenhouse for 2 months and $X$. fastidiosa cells were recovered by culturing of petiole macerates on PWG. The percentage of plants from which any cells of $X$. fastidiosa were recovered was defined as the transmission rate.

Statistical analysis. Binary logistic regression analysis was used to assess the significance of differences in transmission rate due to treatments in various experiments. A binary logistic regression analysis revealed that no significant difference occurred between the blocks (Wald $X^{2}=0.350$, df $3, P=0.678$, and Wald $X^{2}=0.560$, df3, $P=0.07$; for studies in which Temecula and STL transmission in sequential acquisition contexts was assessed, respectively). It also indicated that transmission rate was influenced by treatments (Wald $X^{2}=27.25$, df3, $P<0.001$, and Wald $X^{2}=18.352$, df3, $P<0.001$; for experiments involving the Temecula and STL wild-type strain, respectively). After removing the block factor, pair-wise Fisher exact tests were performed to compare treatments, evaluated at $P<0.05$. Comparison of the number of $X$. fastidiosa cells recovered after attachment to vector 
wings was assessed for each treatment using one-way analysis of variance (ANOVA) followed by an ad hoc Tukey test of log-transformed estimates of cell numbers. The proportion of $X$. fastidiosainfected insects (acquisition rate) or subsequently infected plants (transmission rate) resulting from feeding of $G$. atropunctata on $X$. fastidiosa cells in artificial diets were compared among the three treatments using a $2 \times 3$ contingency table analysis. A pairwise Fisher exact test (evaluated at $P<0.03$ ) was made between those treatments for which a significant overall $t$ test was observed. To compare cell populations in insect heads in different treatments and attachment of cells to wings when suspended in culture supernatants, one-way ANOVAs followed by the Tukey test was used. The ANOVAs were performed on log-transformed estimates of the numbers of cells recovered from each head.

\section{RESULTS}

Vector feeding on $r p f F$-infected plants decreases transmission efficiency of wild-type $X$. fastidiosa. The efficiency with which cells of wild-type $X$. fastidiosa strain Temecula or an rpfF mutant could be transmitted from source plants to healthy grape seedlings by an efficient vector that had previously been allowed to feed on plants infected with either of these strains was tested in greenhouse experiments. A high proportion (ca. 80\%) of the vectors which had not previously fed on plants infected with X. fastidiosa (naïve vectors) transmitted the wild-type strain after a brief acquisition period on plants infected with this strain (Fig. 1A). In contrast, very little transmission (ca. 20\%) of the rpfF mutant by naïve vectors was observed (Fig. 1A). Interestingly, the efficiency with which the wild-type strain was transmitted to healthy plants by vectors that had fed briefly on plants infected with the $r p f F$ mutant was very low $(<5 \%)$, irrespective of whether they had fed before or after feeding on plants infected with the wild-type strain (Fig. 1A). While the frequency of the wild-type strain transmission was reduced over 10-fold compared with transmission by naïve vectors, the frequency with which the $r p f F$ mutant was transmitted remained as low or lower as that by vectors that had fed only on plants infected with the rpfF mutant (Fig. 1A). Surprisingly, the efficiency with which the wild-type strain was transmitted by vectors that had fed on plants infected with the wild-type strain before feeding on plants infected with the $r p f F$ mutant was over 10-fold lower than that in control experiments where naïve vectors fed only on plants infected with the wild-type strain (Fig. 1A). These observations therefore suggested that a factor experienced by sharpshooter vectors feeding on plants infected with the $r p f F$ mutant of $X$. fastidiosa, either before or after acquiring the wild-type strain, interfered with its transmission of the wild-type strain.

To determine whether the apparent inhibitory factors present in plants infected with an $r p f F$ mutant of $X$. fastidiosa strain Temecula were generally inhibitory to the transmission of $X$. fastidiosa, similar transmission experiments with the wild-type strain STL were also performed. A similar inhibition of transmission of this strain in vectors that had fed on plants infected with the $r p f F$ mutant was observed. While strain STL was efficiently transmitted by naïve vectors to healthy grape seedlings (ca. 70\%), transmission efficiency was over twofold lower in vectors that had fed on plants infected with the $r p f F$ mutant either before or after a brief IAP on plants infected with the wild-type strain (Fig. 1B).

Xylem sap from $X$. fastidiosa-infected plants decreases pathogen adhesion to vector wings. As successful transmission of $X$. fastidiosa would require cell retention in vectors after feeding on infected plants, we posited that the lower transmission efficiency of wild-type strains by vectors exposed to sap from plants infected with the $r p f F$ mutant (hereafter termed $r p f F$ sap) could be due to factors in the xylem sap that prevented adherence to the insects. To test this hypothesis we quantified the attachment of cells of a green fluorescent protein (GFP)-marked wild-type strain Temecula that were suspended in xylem sap of different sources to vector hindwings. The chemical features of wing surfaces are thought to be similar to that of the precibarium of sharpshooters $(20,21)$, and wings thus offered a convenient site upon which binding of a GFP-marked wild-type $X$. fastidiosa strain could be assessed. Most $X$. fastidiosa cells bound as individuals to the surface of the wings (Fig. 2B). While there was some spatial variation in the numbers of cells that bound at any particular region of the wing, overall many more cells that were suspended in xylem sap collected from healthy plants (hereafter called healthy sap) bound to wings than those in sap from plants infected with either the wild-type $X$. fastidiosa strain (termed WT sap) or in rpfF sap (Fig. 2A). While over $10^{6}$ cells of X. fastidiosa that were suspended in healthy sap adhered to wing surfaces within a $2 \mathrm{~h}$ incubation period, about 100 -fold fewer cells adhered to wings when suspended in rpfF sap (Fig. 2A). The number of $X$. fastidiosa cells that had attached to wings when suspended in WT sap was about 20-fold less than that of cells suspended in healthy sap (Fig. 2A). It thus appears that a factor that is most abundant in the xylem sap of plants infected with an rpfF mutant, but also present in plants infected with wild-type strains of $X$. fastidiosa, interfere with the binding of this pathogen to the surface of sharpshooter vectors.

To more directly assess the influence of xylem sap of different sources on the process of transmission efficiency of $X$. fastidiosa by sharpshooters, and to avoid the complications associated with using infected plants as a source of inoculum, cells of the pathogen were provided to insect vectors via artificial diets. Cells were suspended at a common cell concentration $\left(10^{8}\right.$ cells $\left./ \mathrm{ml}\right)$ in xylem sap collected from either healthy plants, or plants infected

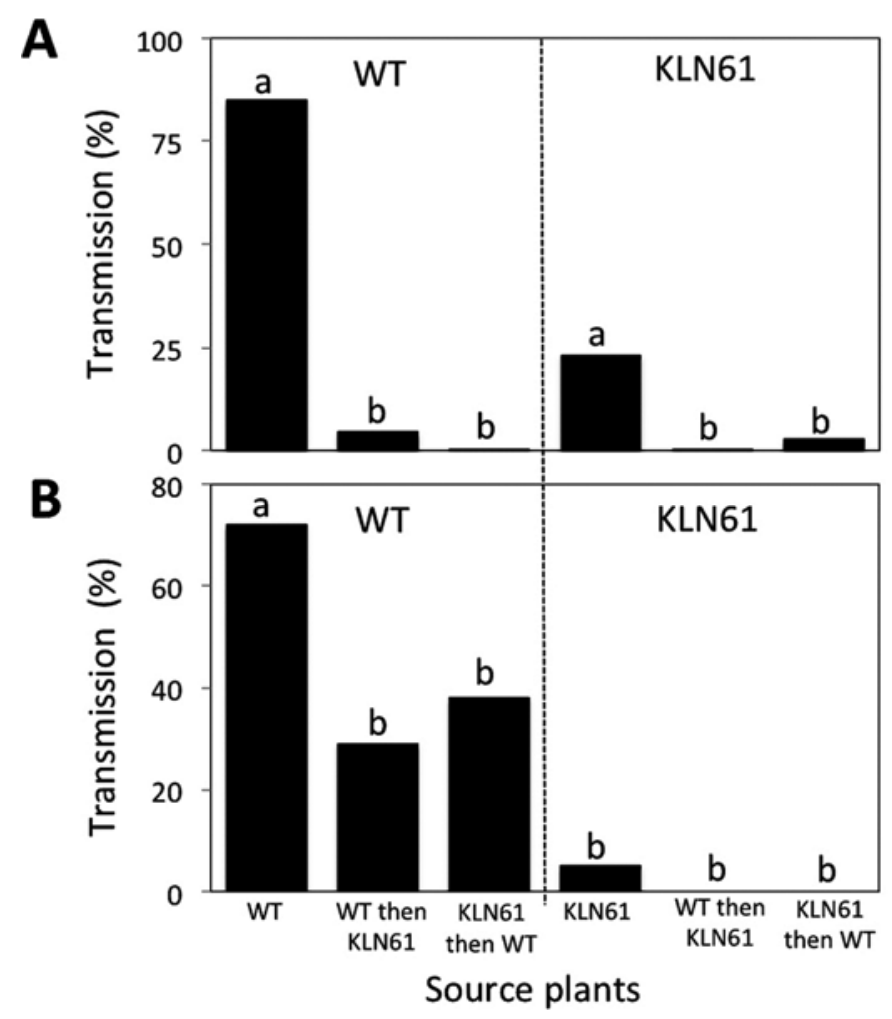

Fig. 1. Transmission of A, Xylella fastidiosa wild-type strains Temecula and STL and B, an rpfF mutant of strain Temecula by vectors fed sequentially on plants infected with these strains. Insects were fed on plants infected with a given strain and then transferred to a healthy plant or to another infected plant before being allowed to inoculate a healthy test plant. Shown are the proportion of plants from which either a wild-type strain or the $r p f F$ mutant could be recovered after a 7 day inoculation access period on healthy plants. Values of a given strain marked with the same letter do not differ significantly $(P<$ 0.05 ) according to pairwise Fisher exact tests. 
with the wild-type or $r p f F$ mutant of $X$. fastidiosa strain Temecula. Graphocephala atropunctata leafhoppers were allowed to feed on such cell suspensions for a 3-h AAP. While by $3 \mathrm{~h}$ of feeding all insects had retained at least some cells of $X$. fastidiosa when it was suspended in healthy sap, only about $60 \%$ of vectors had detectable pathogen populations if cells were suspended in rpfF sap (Fig. 3A). Significantly fewer vectors also had detectable pathogen in their heads if cells were suspended in WT sap. Because many vectors did not retain $X$. fastidiosa, especially when feeding on cells suspended in sap from plants infected with the rpfF mutant (Fig. 3A to $\mathrm{C}$ ), the mean populations achieved in those insects which had retained at least some cells of the pathogen (Fig. 3I to K) were distinguished from the average over all insects (Fig. 3F to $\mathrm{H}$ ) to better define the propensity of cells to form biofilms in the insects under different conditions. While the number of $X$. fastidiosa cells that were retained in vectors that had successfully acquired the pathogen from suspensions of xylem sap from either healthy plants or plants infected with the wildtype pathogen were similar (ca. 100 cells/insect), the number retained in vectors that had fed on cells suspended in $r p f F$ sap was about threefold lower (Fig. 3I). The relative incidence of colonization of insect vectors assessed either 12 or $96 \mathrm{~h}$ after transfer to healthy plants after feeding on artificial diets was similar to that assessed immediately after feeding (Fig. 3B and C). The incidence of colonization of insects that had initially fed on sachets containing cells suspended in healthy sap was significantly higher than that of insects that had fed on cells suspended in rpfF sap (Fig. 3B and C). Likewise, the population size of $X$. fastidiosa in vectors that had acquired at least some cells of the pathogen were about 10 -fold higher $12 \mathrm{~h}$ after transfer to healthy plants than those initially recovered after feeding on sachets (Fig. 3J). Further-

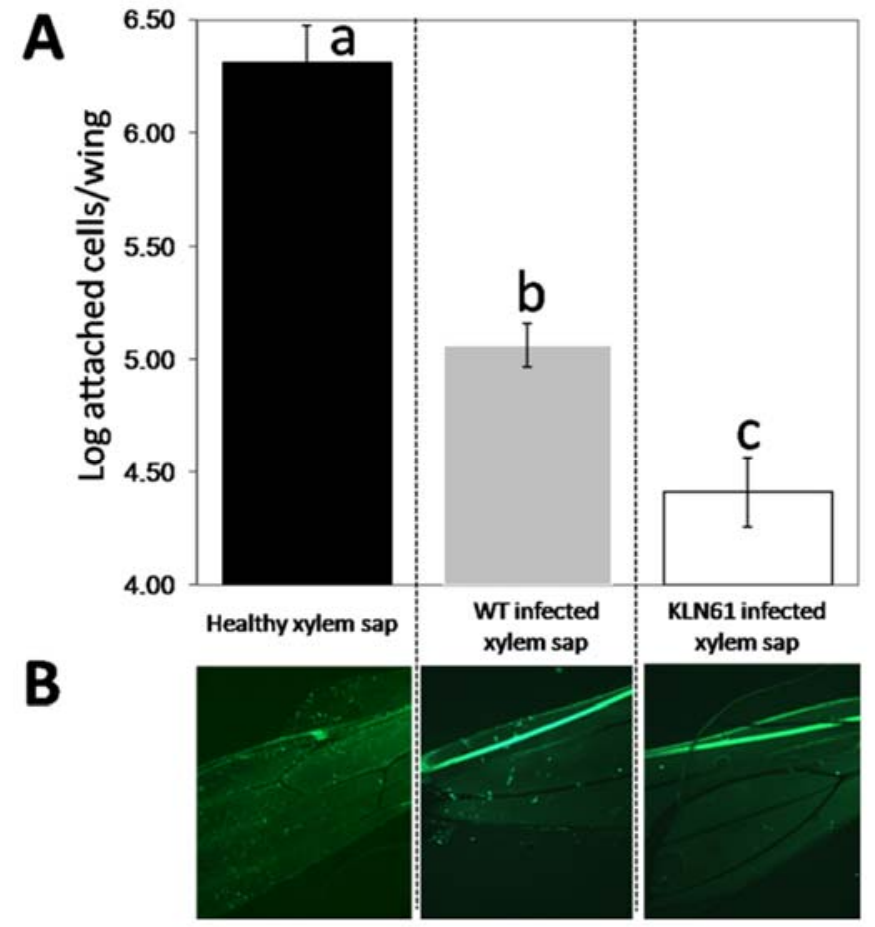

Fig. 2. A, Number of cells of Xylella fastidiosa that were suspended in xylem sap collected from uninfected grape (black bar), or plants infected with either the wild type (gray bar) or $\operatorname{rpfF}$ mutant (white bar) of strain Temecula that were retained on vector wings after incubation for $2 \mathrm{~h}$. The vertical lines represent the standard error of the mean. Means followed by the same letter do not differ significantly $(P<0.05)$ according to an ad hoc Tukey test. B, Attachment of green fluorescent protein-marked cells of the wild-type strain to representative segments of wings corresponding to the conditions above. Note that the bright linear stripes on some segments are autofluorescence associated with veins on the wings. more, populations in insects that had previously fed on cell suspensions in healthy sap were significantly higher than those suspended in $r p f F$ sap (Fig. 3J). After feeding for $96 \mathrm{~h}$ on plants after an initial cell acquisition from sachets, those insects that had retained at least some cells of the pathogen had attained similarly high $X$. fastidiosa population sizes (ca. $10^{4}$ cells/ insect) (Fig. $3 \mathrm{~K}$ ). The lower incidence of retained cells and lower population sizes attained in insect vectors that had fed on $X$. fastidiosa cell suspensions in $r p f F$ sap was associated with a lower transmission efficiency to healthy grape plants (Fig. 3D and E). After feeding on healthy plants for $12 \mathrm{~h}$, the transmission efficiency of vectors that had acquired $X$. fastidiosa from diets containing cells suspended in healthy sap was over threefold higher than that of cells suspended in $r p f F$ sap (Fig. 3D). Similarly low transmission efficiencies by vectors fed on either $r p f F$ or WT sap were seen when vectors were allowed to feed on healthy plants for $96 \mathrm{~h}$ (Fig. 3E).

Supernatant of $X$. fastidiosa grown in vitro decreases cell adhesion to vector wings. While the xylem sap collected from plants infected with an rpfF mutant of $X$. fastidiosa, and to a certain extent also with the wild-type strain, interfered with adhesion of this pathogen to insect surfaces, the studies could not differentiate whether the inhibitory factor was of bacterial or plant origin. To discriminate between these two possibilities the adhesion of a wild-type strain of X. fastidiosa to vector wings when suspended in culture supernatants of a wild-type strain and an $r p f F$ mutant was compared. The number of $X$. fastidiosa cells that had attached to wings that was suspended in uninoculated culture media was much greater (ca. 14-fold) than that of cells suspended in culture supernatants of an $r p f F$ mutant after $24 \mathrm{~h}$ incubation (Fig. 4). Cells suspended in a culture supernatant of a wild-type strain of $X$. fastidiosa also exhibited (ca. fivefold) less adherence to wings than those suspended in culture media itself. These results indicate that an extracellular product of X. fastidiosa is sufficient to account for the interference of adherence of cells in xylem sap of plants infected with this pathogen.

\section{DISCUSSION}

The process of $X$. fastidiosa vector transmission is complex, although the factors that influence the acquisition and retention of the pathogen probably play a predominant role in its success. Sharpshooter vectors withdraw large volumes of liquid from host plants via a very narrow canal, culminating in the precibarium. Because of the rapid rate of liquid flow through this feeding structure (estimated to be in excess of $8 \mathrm{~cm} / \mathrm{s})(25,27)$, features of $X$. fastidiosa that contribute to retention of cells during transit greatly influence the efficiency with which they are subsequently transmitted. DSF-mediated cell-cell signaling has been shown to greatly influence the transmissibility of $X$. fastidiosa (24), as rpfF mutants adhere poorly to glass and do not form abundant biofilms on surfaces as compared to the wild-type strain $(7,9)$. As DSF accumulation results in the up-regulation of several afimbrial adhesins such as HxfA $(8,31)$, it is believed that such cell surface adhesins play a substantial role in the adherence of $X$. fastidiosa to insect vectors. The low transmissibility of rpfF mutants of $X$. fastidiosa seen in earlier studies (24), as well as in this study (Fig. 1 ), is probably associated with its inability to adhere to the mouthparts of sharpshooter vectors. Direct evidence for this model is provided by the observation that $h x f A$ and $h x f B$ mutants of $X$. fastidiosa were deficient in both colonization of the insect foregut as well as in transmission to healthy plants (20). Given that the frequency of $X$. fastidiosa transmission to new plants has been shown to be largely independent of the population size of the pathogen in the heads of sharpshooter vectors $(1,15)$ the ability to colonize vectors rather than the number of cells initially ingested appears to be more important for successful transmission. Few studies of factors affecting transmission efficiency of $X$. fastidiosa have appeared. A previous study showed that se- 
quential exposure of vectors to oleander and grapevine plants infected with different strains of $X$. fastidiosa found some evidence that the successful establishment of one strain might preclude the retention of another strain (10). It seems possible that the disruption of adhesion conferred by X. fastidiosa seen here could explain such a phenomenon.

The premise of this study was based on the hypothesis rpfF mutants could be induced to be more transmissible by exposure to DSF that would be expected to be found in the xylem sap of plants infected with the wild-type strain of this pathogen. This was expected since $r p f F$ mutants of $X$. fastidiosa were known to be at least transiently retained in the heads of sharpshooter vectors (24). No evidence for such phenotypic complementation in trans was observed, since the rpfF mutant exhibited similarly low transmissibility irrespective of whether vectors fed only on plants infected with this mutant, or whether they had fed on plants infected with the wild-type strain either before or after access to $r p f F$-infected plants. Several factors may have accounted for the lack of such complementation. Given that $X$. fastidiosa is spatially segregated in the plant, being restricted to individual xylem vessels harboring variable numbers of cells (23), it is likely that the concentration of DSF varies substantially from one vessel to the next, depending on the local $X$. fastidiosa populations in that vessel. Thus, while feeding on a given vessel an insect vector may be unlikely to harvest DSF-containing xylem sap unless that vessel was colonized by large numbers of cells of wild-type $X$. fastidiosa. Additionally, to benefit from such an exogenous source of DSF an rpfF mutant would have to persist in the vector long enough to benefit from subsequent exposure to DSF.
While we found no evidence of complementation of rpfF mutants in planta, the finding of apparent interference of transmissibility by factors present in plants infected with both wild-type and $r p f F$ mutants of $X$. fastidiosa is of much greater biological

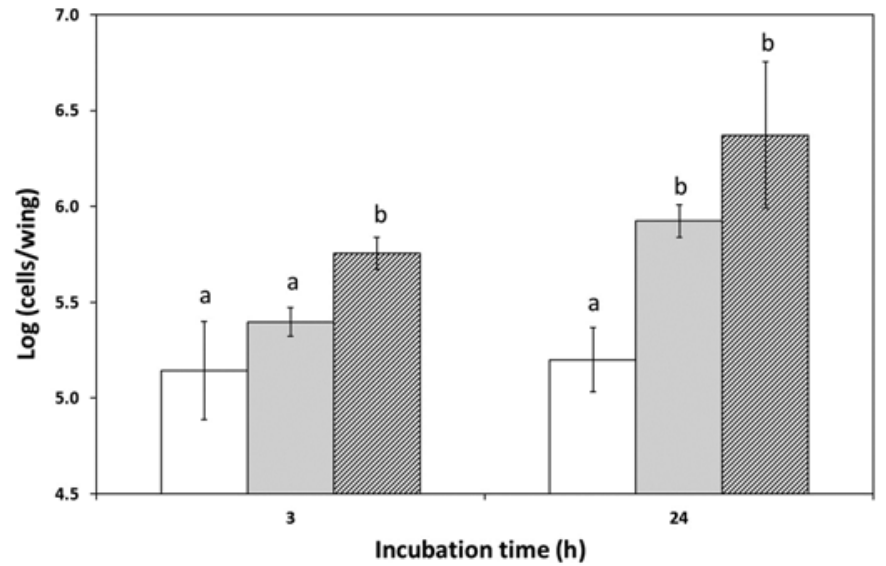

Fig. 4. Attachment of cells of wild-type Xylella fastidiosa strain Temecula to hind wings of glassy-winged sharpshooters when suspended in cell-free supernatants of cultures of a wild-type strain (gray bars) or an $r p f F$ mutant (white bars) that had been grown in PIM6 medium, or in uninoculated PIM6 medium (striped bars) when incubated for the various times shown on the abscissa. Vertical lines represent the standard error of the determination of the mean. Means indicated by the same letter do not differ $(P<0.05)$ by an ad hoc Tukey test.

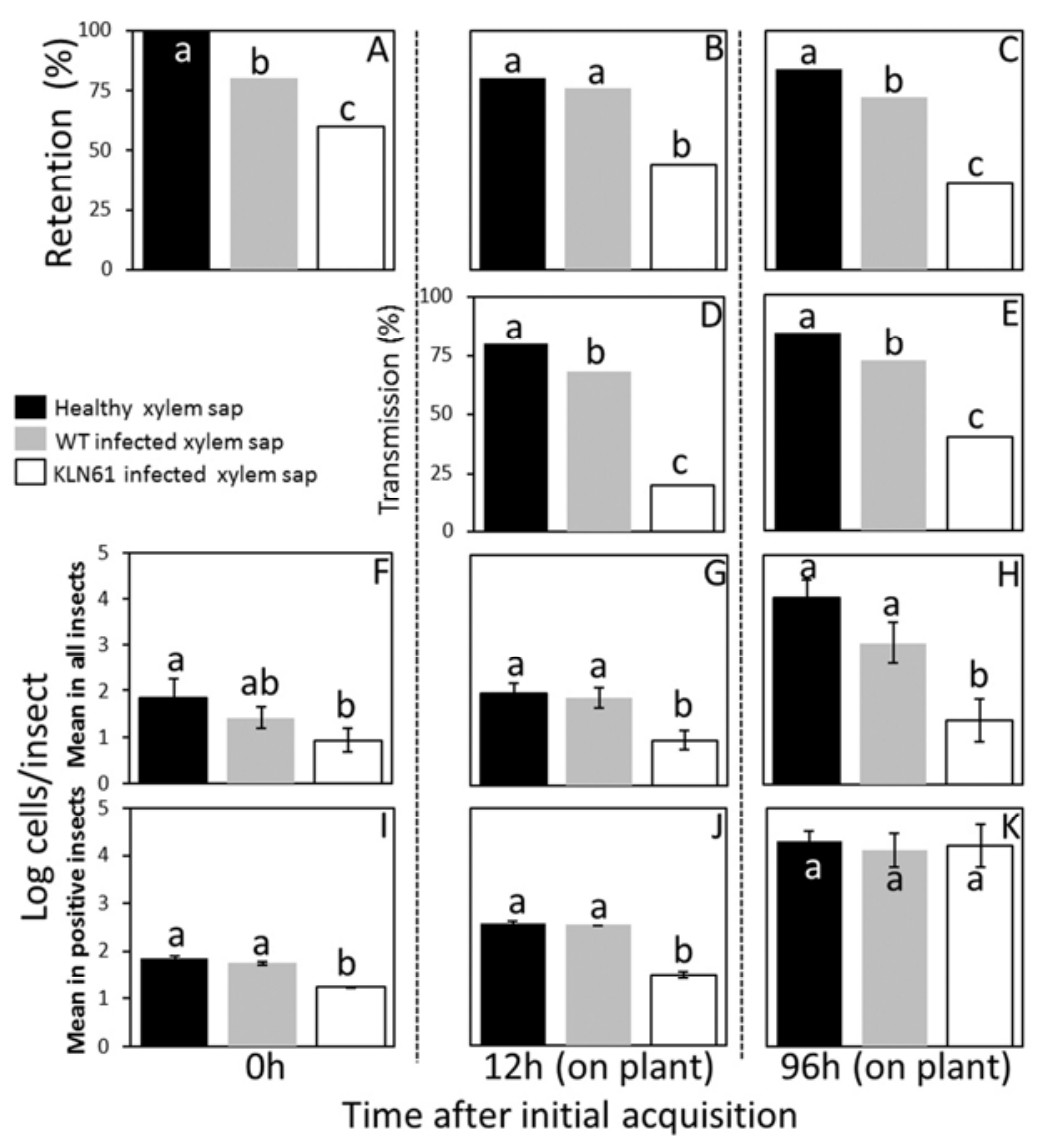

Fig. 3. Percentage of vectors that had acquired detectable numbers of cells of a wild-type strain of Xylella fastidiosa after feeding on artificial diet containing cells suspended in xylem sap from uninfected grape (dark bars) or from plants infected with either the wild type (gray bars) or an $r p f F$ mutant of $X$. fastidiosa strain Temecula (white bars) when assayed immediately after feeding for $\mathbf{A}, 3 \mathrm{~h}$, or after transfer to healthy plants for $\mathbf{B}, 12 \mathrm{~h}$ or $\mathbf{C}, 96 \mathrm{~h}$. Percentage of healthy plants that became infected with $X$. fastidiosa after sharpshooters had fed for either $\mathbf{D}, 12 \mathrm{~h}$ or $\mathbf{E}, 96 \mathrm{~h}$. Population size of $X$. fastidiosa in heads of sharpshooters at various times after feeding on $\mathbf{F}$ and I, cell suspensions in artificial diet or also subsequently on healthy grape plants for $\mathbf{G}$ and $\mathbf{J}, 12 \mathrm{~h}$ or $\mathbf{H}$ and $\mathbf{K}, 96 \mathrm{~h}$. Average population size for all insects assayed (F to $\mathrm{H}$ ) or only those insects with detectable cells of $X$. fastidiosa (I to K) are shown. Vertical lines represent the standard error of the mean. Means followed by the same letter in a given row do not differ significantly $(P<0.05)$ according to pairwise Fisher exact tests. 
significance. The striking reduction in transmissibility of the wild-type strain of $X$. fastidiosa by vectors that had fed on $r p f F$ mutant infected plants can be explained by factors present in the xylem sap that prevented the adherence of the pathogen to insect surfaces. The ability of a wild-type $X$. fastidiosa strain to adhere to wing surfaces or to the mouthparts of vectors was dramatically less when cells were suspended in xylem sap from plants infected with an rpfF mutant. A similar but less dramatic decrease in adherence to the surfaces was also conferred by xylem sap collected from plants infected with the wild-type strain. The substantial decrease in numbers of cells that attached to insect surfaces was strongly linked to a corresponding decrease in the incidence with which insects acquired and retained any detectable $X$. fastidiosa, and pathogen acquisition/retention efficiency was strongly predictive of transmission probability by these vectors. Clearly, only vectors that have successfully acquired the pathogen can transmit it, yet the extensive multiplication of the pathogen that appears to occur within the foregut of the insect after feeding on healthy plants after acquiring the pathogen from feeding on artificial diets suggests that those few cells that are acquired initially during feeding are responsible for the eventual transmission to new host plants. This study shows that successful acquisition is driven by the retention efficiency of cells, which in turn is particularly important in the process of transmission. Factors such as inhibitors of attachment present in the xylem sap would have a correspondingly large impact on the overall rate of transmission.

While the identity of the factor(s) present in xylem sap of plants infected by either the wild-type strain or $r p f F$ mutant of $X$. fastidiosa remains unknown, strong circumstantial evidence suggests that it is of direct bacterial origin rather than a plant factor produced in response to infection with the pathogen. While the attachment of cells of $X$. fastidiosa to sharpshooter wings was much lower when suspended in culture medium in which the rpfF mutant had been grown compared with either uninoculated medium or supernatants of a culture of wild-type X. fastidiosa, it is possible that the inhibitory factor is a modification of some component of the growth medium. However, it would seem unlikely that the same modified environmental component would have been produced in both culture medium and in the plant given the different chemical milieus present. The most parsimonious explanation is that $X$. fastidiosa releases some component into both the growth medium and xylem sap that is responsible for interfering with its own attachment. Given that the attachment disruption that was conferred by growth of the wild-type strain was simply quantitatively less than that conferred by an $r p f F$ mutant, it is reasonable to suspect that the same anti-adhesive process was operative in both strain, and that the release of the factor is suppressed by accumulation of DSF. That is, $X$. fastidiosa may commonly modify its environment in a way that would tend to reduce the efficiency with which it is transmitted by insects. This process is apparently suppressed in those cells which have reached high cell density and in which DSF would have accumulated (9). Alternatively, it is also possible that $X$. fastidiosa modifies environmental constituents that might be required for attachment, but this seems less likely since attachment interference was seen in several different culture media and the plant environment; it seems unlikely that an $r p f F$-dependent trait would be operative in all such settings.

The presence of factors that interfere with insect transmission of $X$. fastidiosa is consistent with a developing model of the disease process in which DSF signaling is used to partition the population of cells of this pathogen to optimize fitness in the plant while enabling it to be transmitted to new host plants. $X$. fastidiosa is present in a large number of xylem vessels in infected grape stems and petioles, yet the population size varies from only a few cells to many thousands of cells per vessel (23). It is presumed that the concentration of DSF within a given vessel is proportional to the number of cells of $X$. fastidiosa present in that vessel, although some dispersal of DSF might occur, leading to low concentrations of DSF even in uncolonized vessels. It is unlikely that high concentrations of DSF would be found in the vicinity of cells unless they were present in high local concentration in a colonized vessel. DSF accumulation is associated with traits such as induction of fimbrial and afimbrial adhesins as well as suppression of type IV pili and the production of extracellular enzymes, all of which would tend to restrict the ability of the pathogen to move within the plant $(9,31)$. Given that the majority of vessels in infected plants harbor relatively few cells of $X$. fastidiosa $(16,23)$, it is presumed that most do not experience sufficient concentrations of DSF to suppress their movement through the plant, and thus can be considered to be actively exploring the plant. Only in those vessels in which high cell concentrations are achieved (and in which DSF accumulates) will cells become sufficiently adhesive to be efficiently acquired by insect vectors. High adhesiveness associated with DSF signaling appears to be essential for acquisition of $X$. fastidiosa (24). Thus, cells of $X$. fastidios $a$ in infected plants appeared to be partitioned into subpopulations that are either (i) actively moving and multiplying in plants or (ii) incapable of movement but which can be acquired by insect vectors. We postulate that unknown factors are preferentially released from those cells of $X$. fastidios $a$ that are present in low numbers in vessels, and which are therefore most highly motile. Such factors would logically be suppressed by DSF signaling, and would be maximally produced by an $r p f F$ mutant. The highest concentration of such an anti-adhesive factor would be present in the xylem sap of plants infected with an $r p f F$ mutant of $X$. fastidiosa not only because such mutants would maximally produce such a factor, but also because they are in higher numbers due to their unrestricted growth compared with the wild-type strain (9). Thus, xylem sap recovered from plants infected with a wild-type strain would be a mixture from xylem vessels colonized by low numbers of cells of $X$. fastidiosa (in which the antiadhesive factor would be maximally produced on a per cell basis) as well as from vessels harboring high populations of the pathogen, although the blockage of such vessels by cells and tyloses may reduce the recovery of sap from such vessels. In this model, those most adhesive cells of $X$. fastidiosa (present in vessels having the highest numbers of cells of this pathogen) could be most efficiently retained and thereafter vectored by sap-sucking insects without the interference that an anti-adhesive factor produced by more solitary cells in the plant would have on the transmission process. The presumptive anti-adhesive factor could play a major role in facilitating the movement of $X$. fastidiosa throughout the plant and further work to elucidate its nature and contributions to this process are warranted.

\section{ACKNOWLEDGMENTS}

We thank R. Koutsoukis for technical assistance with experiments and S. Purcell for discussion and assistance. This material is based upon work supported by the American Vineyard Foundation, California Competitive Grant Program for Research in Viticulture and Enology, and the Pierce's disease and glassy-winged sharpshooter control program of California Department of Food and Agriculture and the USDA.

\section{LITERATURE CITED}

1. Almeida, R. P. P., and Purcell, A. H. 2003. Transmission of Xylella fastidiosa to grapevines by Homalodisca coagulata (Hemiptera: Cicadellidae). J. Econ. Entomol. 96:264-271.

2. Almeida, R. P. P., and Purcell, A. H. 2006. Patterns of Xylella fastidiosa colonization on the precibarium of leafhoppers vectors relative to transmission to plants. Anal. Entomol. Soc. Am. 99:884-890.

3. Baccari, C., and Lindow, S. E. 2011. Assessment of the process of movement of Xylella fastidiosa within susceptible and resistant grape varieties. Phytopathology 101:77-84.

4. Barber, C. E., Tang, J. L., Feng, J. X., Pan, M. Q., Wilson, T. J., Slater, H., Dow, J. M., Williams, P., and Daniels, M. J. 1997. A novel regulatory 
system required for pathogenicity of Xanthomonas campestris is mediated by a small diffusible signal molecule. Mol. Microbiol. 24:555-566.

5. Beaulieu, E., Ionescu, M., Chatterjee, S., Yokota, K., Trauner, D., and Lindow, S. E. 2012. Characterization of a diffusible signaling factor from Xylella fastidiosa. mBio 4(1). doi:10.1128/mBio.00539-12

6. Brlansky, R. H., Lee, R. F., Timmer, L. W., Purcifull, D. E., and Raju, B. C. 1982. Immunofluorescent detection of xylem-limited bacteria in situ. Phytopathology 72:1444-1448.

7. Chatterjee, S., Almeida, R. P. P., and Lindow, S. E. 2008. Living in two worlds. The plant and insect lifestyles of Xylella fastidiosa. Annu. Rev. Phytopathol. 46:243-271.

8. Chatterjee, S., Killiny, N., Almeida, R. P. P., and Lindow, S. E. 2010. Role of cyclic diGMP in Xylella fastidiosa biofilm formation, plant virulence, and insect transmission. Mol. Plant-Microbe Interact. 23:1356-1363.

9. Chatterjee, S., Newman, K. L., and Lindow, S. E. 2008. Cell-cell signaling in Xylella fastidiosa suppresses movement and xylem vessel colonization in grape. Mol. Plant-Microbe Interact. 21:1309-1315.

10. Costa, H. S., Guzman, A., Hernandez-Martinez, R., Gispert, C., and Cooksey, D. A. 2006. Detection and differentiation of Xylella fastidiosa strains acquired and retained by glassy-winged sharpshooters (Hemiptera: Cicadellidae) using a mixture of strain-specific primer sets. J. Econ. Entomol. 99:1058-1064

11. Daugherty, M. P., and Almeida, R. P. P. 2009. Estimating Xylella fastidiosa transmission parameters: Decoupling sharpshooter number and feeding period. Entomol. Exp. Appl. 132:84-92.

12. Francis, M., Lin, H., Cabrera-La Rosa, J. C., Doddapaneni, H., and Civerolo, E. L. 2006. Genome-based PCR primers for specific and sensitive detection and quantification of Xylella fastidiosa. Eur. J. Plant Pathol. 115:203-213.

13. Freitag, J. H. 1951. Host range of Pierce's disease virus of grapes as determined by insect transmission. Phytopathology 41:920-934.

14. Hewitt, W. B., Frazier, N. W., and Freitag, J. H. 1949. Pierce's disease investigations. Hilgardia 19:207-264.

15. Hill, B. L., and Purcell, A. H. 1995. Acquisition and retention of Xylella fastidiosa by an efficient vector, Graphocephala atropunctata. Phytopathology 85:209-212.

16. Hopkins, D. L. 2005. Biological control of Pierce's disease in the vineyards with strains of Xylella fastidiosa benign to grapevine. Plant Dis. 89:1348-1352.

17. Hopkins, D. L., and Purcell, A. H. 2002. Xylella fastidiosa: Cause of Pierce's disease of grapevine and other emergent diseases. Plant Dis.
86:1056-1066.

18. Houston, B. R., Esau, K., and Hewitt, W. B. 1947. The mode of vector feeding and the tissues involved in the transmission of Pierce's disease virus in grape and alfalfa. Phytopathology 37:247-253.

19. Killiny, N., and Almeida, R. P. P. 2009. Host structural carbohydrate induces vector transmission of a bacterial plant pathogen. Proc. Natl. Acad. Sci. USA 106:22416-22420.

20. Killiny, N., and Almeida, R. P. P. 2009. Xylella fastidiosa afimbrial adhesins mediate cell transmission to plants by leafhoppers vectors. Appl. Environ. Microbiol. 75:521-528.

21. Killiny, N., Prado, S. S., and Almeida, R. P. P. 2010. Chitin utilization by the insect-transmitted bacterium Xylella fastidiosa. Appl. Environ. Microbiol. 76:6134-6140.

22. Lopes, J. R. S., Daugherty, M. P., and Almeida, R. P. P. 2009. Contextdependent transmission of a generalist plant pathogen: Host species and pathogen strain mediate insect vector competence. Entomol. Exp. Appl. 131:216-224.

23. Newman, K. L., Almeida, R. P. P., Purcell, A. H., and Lindow, S. E. 2003. Use of a green fluorescent strain for analysis of colonization of Vitis vinifera by Xylella fastidiosa. Appl. Environ. Microbiol. 69:73197327.

24. Newman, K. L., Almeida, R. P. P., Purcell, A. H., and Lindow, S. E. 2004 Cell-cell signaling controls Xylella fastidiosa interactions with both insects and plants. Proc. Natl. Acad. Sci. USA 101:147-152.

25. Purcell, A. H. 1990. Homopteran transmission of xylem-inhabiting bacteria. Pages 243-266 in: Advances in Disease Vector Research, Vol. 5. K. F. Harris, ed. Springer-Verlag, New York.

26. Purcell, A. H., and Finlay, A. 1979. Evidence for non-circulative transmission of Pierce's disease bacterium by sharpshooter leafhoppers. Phytopathology 69:393-395.

27. Purcell, A. H., Finlay, A., and McLean, D. L. 1979. Pierce's disease bacterium: Mechanism of transmission by leafhopper vectors. Science 206:839-841.

28. Purcell, A. H., and Hopkins, D. L. 1996. Fastidious xylem-limited bacterial plant pathogens. Annu. Rev. Phytopathol. 34:131-151.

29. Severin, H. H. P. 1949. Transmission of the virus of Pierce's disease by leafhoppers. Hilgardia 19:190-202.

30. Severin, H. H. P. 1950. Spittle-insect vectors of Pierce's disease virus. II. Life history and virus transmission. Hilgardia 19:357-382.

31. Wang, N., Li, J. L., and Lindow, S. E. 2012. RpfF-dependent regulon of Xylella fastidiosa. Phytopathology 102:1045-1053. 